\section{TRANSFERENNCIA IN VITRO DE IMUNIDADE CELULAR PARA LINFÓCITOS HUMANOS A UM PEPTÍDEO SINTÉTICO DO VÍRUS DA AIDS (HIV-1) COM RNA IMUNE XENOGÊNICO}

O presente trabalho foi desenvolvido com um peptídeo sintético de 12 aminoácidos (LeuGly-Ile-Trp-Gly-Cys-Ser-Gly-Lys-Leu-Lle-Cys), denominado p12. Esse peptídeo corresponde a um epítopo imunodominante e altamente coservado da glicoproteína 41 do HIV-1 (Human Immunodeficiency Virus-1).

O RNA imune (RNAi) anti-p12 foi obtido de baço e linfonodos de carneiros imunizados com o p12. O objetivo principal deste estudo foi verificar se o RNAi anti-p12 é capaz de transferir in vitro resposta imune celular para linfócitos humanos. Portanto, foi testada a possibilidade de ocorrer uma transferência xenogênica (carneiro para o homem) de imunidade celular com RNAi anti-p12. Além disso, este trabalho foi a primeira tentativa de se transferir imunidade celular com RNAi para um antígeno (p12) que possui um número de resíduos de aminoácidos considerado no limite da capacidade de reconhecimento do sistema imune. A avaliação da transferência de imunidade celular foi feita através do Teste de Inibição da Aderência de Leucócitos (Teste LAI) e do Ensaio de Transformação Blástica. O uso destes dois ensaios imunológicos permitiu um estudo comparativo entre o Teste LAI e o Ensaio de Transformação Blástica quanto à capacidade de detectar o fenômeno de transferência de imunidade celular com o RNAi, o que constitui outro aspecto original deste trabalho.

Neste estudo, utilizou-se linfócitos de 15 doadores, cujos soros foram negativos para anticorpos anti-HIV-1. Foi possivel realizar a transferência de resposta imune celular com RNAi anti-p12 em $9(60 \%)$ casos, os quais foram denominados de doadores responsivos, sendo que os outros $6(40 \%)$ casos correspondem aos doadores não responsivos. Uma observação importante foi que os doadores responsivos e não responsivos detectados pelo Teste LAI foram rigorosamente os mesmos observados através do Ensaio de Transformação Blástica.

Recebido para publicação em 17/03/95.

\section{IN VITROTRANSFERENCE OF CELLULAR IMMUNITY TO HUMAN LYMPHOCYTES BYA SYNTHETIC PEPTIDE OF THE AIDS VIRUS OF A XENOGENIC IMMUNE RNA}

The present work was carried oud with the synthetic peptide of 12 amino acids(Leu-Gly-IleTrp-Gly-Cys-Ser-Gly-Lys-Leu-Ile-Cys) referred to as p12. This peptide corresponds to an immunodominant and well conserved epitope of the glycoprotein 41 of HIV-1 (Human Immunodeficiency Virus-1).

The anti-p12 immune RNA (iRNA) was obtained from the spleen and lymph nodes of sheep immunized with the p12. The main purpose of this study was to verify if the anti-p12 iRNA is able to transfer inz vitro immune cellular response to human lymphocytes. Therefore, it was tested the possibility to induce a xenogenic transfer (sheep to man) of cellular immunity with the anti-p12 iRNA. In adition, this work was the first attempt to transfer cellular immune reactivity to an antigen (p12) with a number of amino acid residues near the limit of recognition of the immune system. The transfer of cellular immunity was assessed by the leukocyte adherence inhibition test (LAI test) and the blastic transformation assay which for the first time allowed a comparison between two immunological assays in regard to their capacities to detect cellular immunity transfer with iRNA.

This study was performed with lymphocytes from 15 donors whose sera were negative to antibodies against HIV-1. It was possible to transfer cellular immune response with anti-p12 iRNA in $9(60 \%)$ subjects referred to as "responsive donors" while other $6(40 \%)$ subjects were called "non responsive donors". An important finding was the observation that the responsive and non responsive donors detected by the LAI test were exactly the same as that obtained with the blast transformation assay.

It was also found that the human lymphocytes incubated with the anti-p12 iRNA were not able to recognize a synthetic peptide of 11 amino acids whose primary structure (Ile-SerArg-Pro-Phe-Gly-Ser-Pro-Pro-Phe-Arg) is completly different from that of $\mathrm{p} 12$, indicating that this phenomenon is antigen specific. 
Resumo de Tese. Sawan FM. Transferência in vitro de imunidade celular para linfócitos humanos a um peptídeo sintético do vírus da AIDS (HIV-1) com RNA imune xenogênico. Revista da Sociedade Brasileira de Medicina Tropical 28:427-428, out-dez, 1995.

Verificou-se ainda que linfócitos humanos incubados com RNAi anti-p12 não foram capazes de reconhecer um peptídeo sintético de 11 aminoácidos, cuja estrutura primária (Ile-Ser-ArgPro-Pro-Phe-Gly-Ser-Pro-Phe-Arg) é totalmente diferente do p12, indicando que esse fenômeno é antígeno específico. Além disso, demonstrou-se que linfócitos humános tratados com RNAi antimelanoma B16 não reconhecem o p12, mostrando que a informação específica para esse peptídeo sintético é dada somente pelo RNAi anti-p12. O tratamento deste RNAi com RNase aboliu totalmente a sua atividade imunológica, o que indica a integridade da cadeia polinucleotídica do RNAi anti-p12 é essencial para que o mesmo seja capaz de sensibilizar os linfócitos humanos.

Admite-se que os linfócitos T citotóxicos desempenham um papel importante na defesa contra as infecções virais, inclusive pelo HIV. É fato conhecido que os peptídeos sintéticos geralmente não são capazes de induzir in vivo esse tipo de célula citotóxica, o que já foi demonstrado em vários sistemas com o uso sistêmico do RNAi. Os dados obtidos in vitro no presente trabalho representam um forte estímulo para se abordar esse fenômeno in vivo, o que poderá contribuir para o esclarecimento de uma nova alternativa de imunomodulação nos casos de infecção pelo HIV.
Moreover, it was demonstrated that the human lymphocytes treated with anti-melanoma B16 iRNA did not recognize the $\mathrm{p} 12$, showing that the specific information for the $\mathrm{p} 12$ is only obtained by the anti-p12 iRNA. The treatment of this iRNA with RNase totally abolished its immunological activity, indicating that the integrity of the polynucleotyde chain of the anti-p12 iRNA is essential in order to sensitise the human lymphocytes.

It is well known that the cytotoxic $T$ lymphocytes play an important role in the defense against viral infections, including the case of HIV infection. It has been established that synthetic peptides in general are not able to induce this type of cytotoxic cell in vivo although this has been demonstrated in several systems by injecting iRNA. The in vitro results obtained in the present work represent a strong stimulus to study this phenomenon in vivo which could contribute to establish alternatives of immunomodulation in the case of HIV infection.

\section{Fabim Miguel Sawan}

Tese apresentada à Faculdade de Medicina de Ribeirão Preto da Universidade de São Paulo para obtenção do Título de Mestre.

Ribeirão Preto, SP, Brasil, 1992. 